\title{
Температурные ограничения метасоматоза Бакальских сидеритовых месторождений по геохимическим данным
}

\author{
М.Т. Крупенин \\ Институт геологии и геохимии УрО РАН, Екатеринбург, 620016, ул. Ака- \\ демика Вонсовского, 15. E-mail: krupenin@igg.uran.ru \\ (Статья поступила в редакциюю 17 февраля 2017 г.)
}

На основе количественных микрозондовых определений состава парагенезов анкерит-сидерит в семи точках, приуроченных к разным частям Бакальского рудного поля, показано, что околорудные анкериты в западной и центральной частях рудного поля отличаются по средним концентрациям $\mathrm{FeCO}_{3}$ (соответственно 14,21 и 20,84 мас. \%), в то время как в составе сидероплезита этих объектов нет выраженных различий. Расчет температур магнезиально-железистого метасоматоза на основе анкерит-сидеритового и анкерит-брейнеритового геотермометров показал их совпадение при $250^{\circ} \mathrm{C}$ и выше. Средние температуры сидеритового метасоматоза составляют в центральной части Бакальского рудного поля $250-270^{\circ} \mathrm{C}$, в периферической части - не выше $190-220^{\circ} \mathrm{C}$ и не зависят от положения сидеритовой залежи в стратиграфическом разрезе бакальской свиты.

Ключевые слова: метасоматоз, доломит, анкерит, брейнерит, сидерит, геотермометр, рифей.

DOI: 10.17072/psu.geol.16.2.167

\section{Введение}

Бакальские сидеритовые месторождения, имеющие суммарные запасы сидеритовой руды более 1 млрд т, являются крупнейшими в мире в классе гидротермально-метасоматических (Яницкий, Сергеев, 1962; Prochaska, Krupenin, 2013) и эксплуатируются более 250 лет. Благодаря детальным геологоразведочным и эксплуатационным работам получены подробные представления о геологическом строении Бакальского рудного поля (Яницкий, Сергеев, 1962), минералогии и геохимии руд и вмещающих терригеннокарбонатных и изверженных пород (Заварицкий, 1939; Тимесков, 1963 и др.). Метасоматическая природа образования пластообразных сидеритовых залежей подтверждена многочисленными аргументами (Анфимов, 1991; Крупенин, 1999), а изотопные исследования $\mathrm{Rb}-\mathrm{Sr}$ и $\mathrm{U}-\mathrm{Pb}$ си- стем позволили определить время метасоматоза - около 1010+100 млн лет (Кузнецов и др. 2005). Проявление метасоматоза совпадает с этапом крупной тектонической перестройки в регионе на границе среднего и позднего рифея, с которым было связано формирование анкеритовой минерализации, а также магнезитовое, флюоритовое и барит-полиметаллическое оруденение (Крупенин, 2004). В то же время остается слабо изученным механизм сидеритового метасоматоза. Источники железосодержащих флюидов, как предполагается по данным изучения петрохимии вмещающих пород (Анфимов и дp, 1984), а также $\mathrm{Rb}-\mathrm{Sr}$ изотопной систематики (Кузнецов и др. 2005), связаны с элизионно-катагенетическими процессами во вмещающих глинистых породах бакальской свиты. В то же время изучение флюидных включений в сидеритах указало на рассольную природу рудных флюи- 
дов и связь с эвапоритовым источником (Prochaska, Krupenin, 2013). Другими авторами рассматривалась постмагматическая природа рудных растворов (Заварицкий, 1939; Тимесков, 1963; Яницкий, Сергеев, 1962 и др.). До сих пор неясными остаются и физико-химические параметры рудоотложения, в том числе температурные рамки этого крупнейшего в истории Земли проявления $\mathrm{Mg}-\mathrm{Fe}$ метасоматоза в осадочных терригенно-карбонатных толщах. В статье рассмотрены температурные параметры сидеритообразования по геохимическим данным на базе двух геотермометров (сидерит-анкеритовый по (Annovitz, Essene, 1987) и анкеритбрейнеритовый по Мартынову (1990)).

\section{Особенности геологического строения рудного поля}

Рудное поле приурочено к Бакальской синклинали, осложняющей южное замыкание Тараташского антиклинория в северной части Башкирского мегантиклино- рия. Последний представляет собой крупную структуру в составе ЦентральноУральского поднятия, в которой обнажены породы рифея. Сидеритовые месторождения локализованы в карбонатных пачках верхнебакальской подсвиты бакальской свиты нижнего рифея (бурзяния) в области их примыкания к несогласно налегающим кварцитовидным песчаникам зигальгинской свиты среднего рифея (юрматиния) (рис. 1). Глубина размыва отложений верхнебакальской подсвиты составляет до 700 м (Яницкий, Сергеев, 1962). В подсвите мощностью до 900 м выделяются пять карбонатных пачек, разделённых терригенно-глинистыми. Рудное поле разбито многочисленными взбросами и сдвигами амплитудой до 500 м и осложнена складками разных порядков, служащих естественными границами отдельных месторождений. Преобладает Ю3-СВ ориентировка простирания тектонических элементов, но имеется несколько сдвигов субширотного простирания.

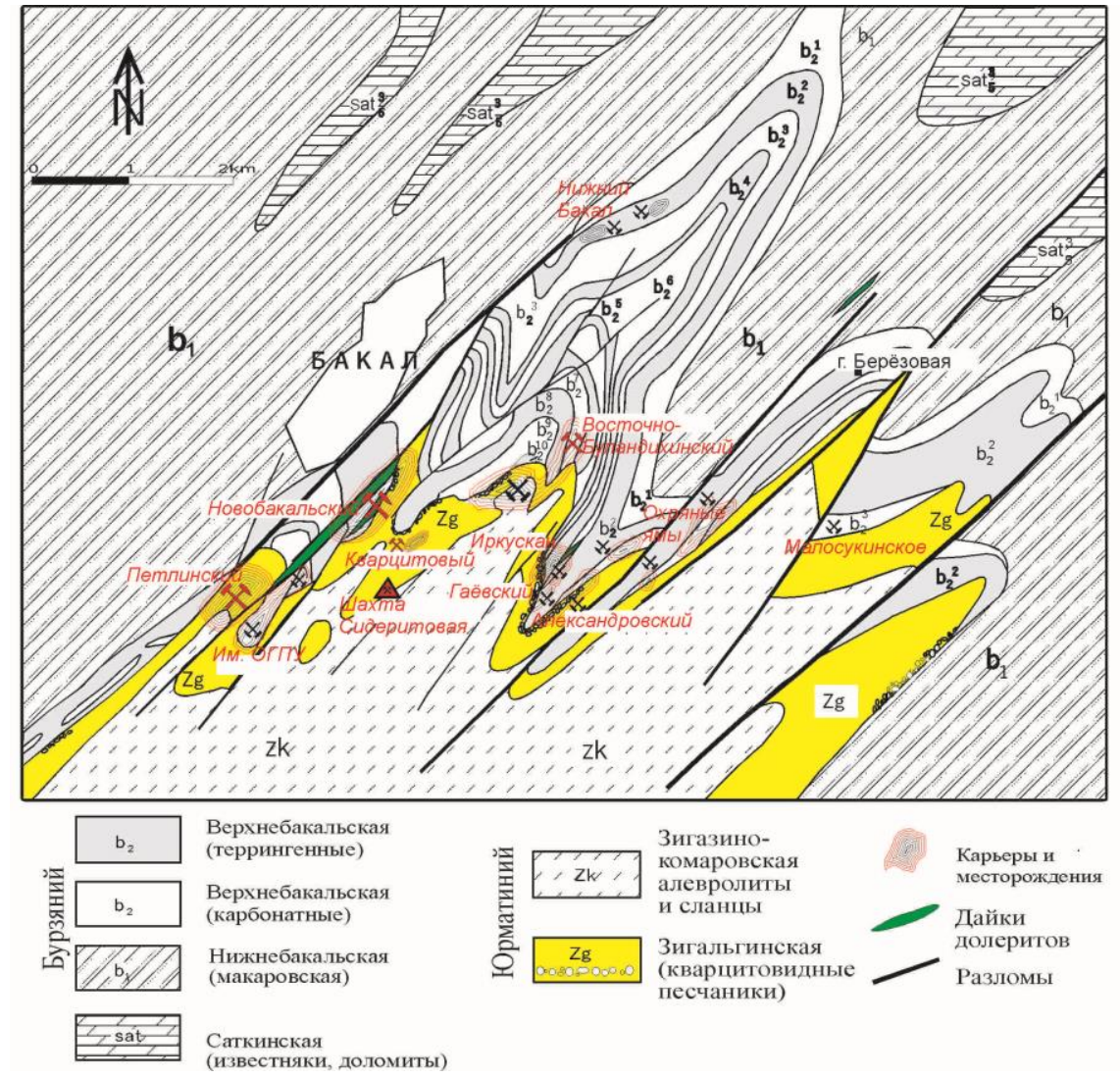

Рис. 1. Схематическая геологическая карта Бакальского рудного поля (по Яниикому и Сергееву (1962) с изменениями) 
Отложения нижнего рифея всего бакальского района прорваны долеритовыми дайками, в том числе Главной дайкой мощностью до 100 м в западной части рудного поля (между месторождениями Петлинским и Новобакальским), комагматичными машакскому рифтогенному событию в начале юрматиния (около 1380 млн лет назад).

Рудные залежи имеют гнездо-, штокои пластообразные формы, размеры их достигают десятков метров по мощности и сотен метров по простиранию. Они обладают многочисленными признаками наложенного образования по осадочным карбонатным породам: границы сидеритовых тел пересекают элементы слоистости, строматолитовые текстуры (рис. 2,a), залежи магнезитов в пачке $\mathrm{b}_{2}{ }^{3}$; наблюдаются останцы доломита внутри сидеритовых тел (рис. 2,б); имеются признаки доскладчатого рудообразования; сидериты выклиниваются около контактовых зон мраморизации с крупными долеритовыми дайками и силлами, реже наблюдается сидеритизация базитовых даек с сохранением офитовой структуры, кроме того, обнаружены отдельные послерудные долеритовые дайки, образующие в сидеритах

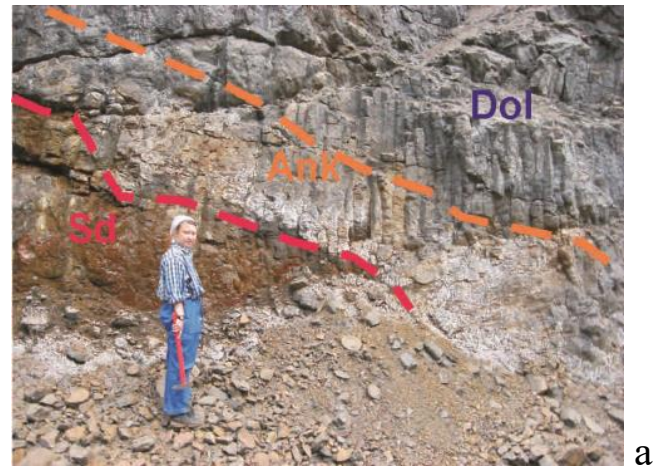

экзоконтактовую зону тонковкрапленного магнетита (Крупенин, 1999). Во всем рудном поле наблюдается четкая метасоматическая зональность: сидеритовые залежи во вмещающих известняках всегда окружены конвертом доломитов, переходящих в анкериты в непосредственной близости с рудными телами (Демчук и др, 2003; Тимесков, 1963).

Предполагается, что поверхность межформационного несогласия между отложениями бурзяния и юрматиния явилась рудораспределяющей зоной, в то время как часть разломных зон играла роль рудоподводящих каналов. Именно поэтому наблюдается многоэтажное строение рудных залежей, когда в одном месторождении оруденение развивается в 2-3 пачках, к примеру, разрабатываемые шахтой месторождения Шиханское и Рудничное, а также карьеры Иркускан, Новобакальский.

\section{Методика исследований}

Контактовые зоны сидерита и доломита из сидеритовых залежей (7 проб из различных месторождений Бакальского рудного поля) были изучены с помощью

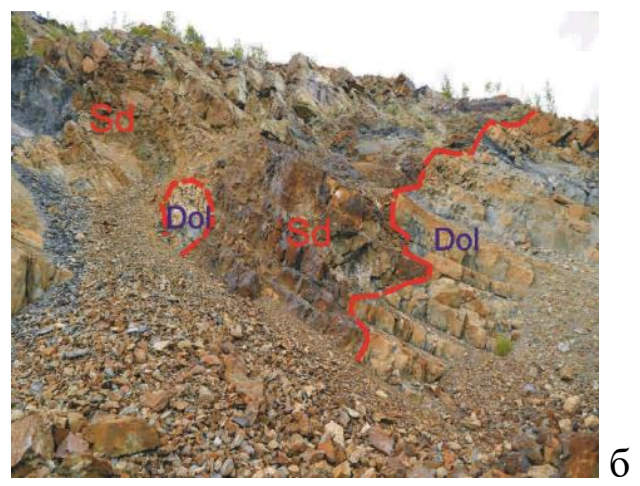

Рис. 2. Дискордантное положение сидеритовых залежей относительно осадочных карбонатных пород: a - контакт сидерита (Sd) с анкеритом (Ank) и доломитом (Dol) в мощном строматолитовом биогерме, пачка $b_{2}{ }^{5}$ (карьер Иркускан); б - секущие слоистость итоки сидерита с останиами доломита в пачке $b_{2}{ }^{9}$ (Восточно-Буландихинский карьер)

дифрактометрического и термического анализов для подтверждения их минерального состава (ИГГ УрО РАН, Екатеринбург). Из хорошо выраженных контактовых анкерит-сидеритовых зон были из- готовлены полированные шлифы для изучения под электронным микроскопом в Техническом университете Берлина, ФРГ (Cameca-Grundgerät Camebax-Microbeam). Концентрация железа определялась по 
интенсивности звукового сигнала с последующим точным определением состава парагенетических анкерита и сидерита микроанализатором (в пересчёте на $\mathrm{FeCO}_{3}, \mathrm{MgCO}_{3}, \mathrm{MnCO}_{3}, \mathrm{CaCO}_{3}, \mathrm{SiO}_{2}$ ). Для расчета возможных температур метасоматоза были использованы анкеритсидеритовый (Annovitz, Essene, 1987) и анкерит-брейнеритовый (Мартынов, 1988, 1990) термометры. Для анкеритсидеритового термометра проведена проверка составов бинарных растворов в системе $\mathrm{CaCO}_{3}-\mathrm{MgCO}_{3}-\mathrm{FeCO}_{3}$ природных карбонатов, скомбинированных с экспериментальными данными для температур гидротермального процесса $\left(250-700^{\circ} \mathrm{C}\right)$. В результате была получена приближенная линейная зависимость температуры минералообразования от коэффициента $\mathrm{K}_{\mathrm{D}}$, который связан с составом сосуществующих карбонатных минералов:

$K_{D}=\frac{\left(X^{\mathrm{FeCO}} / X^{M_{g} \mathrm{CO} 3}\right) A n k}{\left(X^{\mathrm{FeCO}} / X^{M_{g} \mathrm{CO}}\right) S d}=-0,691+0,00176 T(T, \mathrm{~K})$, где:

$X^{\mathrm{MgCO} 3}=\frac{X^{\mathrm{MgCO} 3}}{X^{\mathrm{CaCO}_{3}}+X^{\mathrm{MgCO} \mathrm{CO}}+X^{\mathrm{FeCO} 3}+X^{\mathrm{MnCO3}}}$, $X^{\mathrm{FeCO} 3}=\frac{X^{\mathrm{FeCO} 3}+X^{\mathrm{MnCO} 3}}{X^{\mathrm{CaCO} 3}+X^{\mathrm{MgCO} 3}+X^{\mathrm{FeCO} 3}+X^{\mathrm{MnCO} 3}}$, $T\left({ }^{\circ} C\right)=\frac{K D+0,691}{0,00176}-273$.

Применение анкерит-брейнеритового термометра как с использованием литературных данных, так и результатов собственных экспериментов, адаптировано в программе на языке BASIC и основано на оценке железистости когенетичных анкерита и брейнерита. В этом термометре используются только данные по содержанию $\mathrm{FeO}$ и $\mathrm{MgO}$ в изучаемых карбонатных минералах.

Зависимость концентраций железа в анкерите и брейнерите только от температуры и независимость от давления, обусловленная очень малым объемным эффектом соответствующей реакции (Мартынов, 1990), позволяет использовать указанные геохимические соотношения составов парагенетических карбонатов в ка- честве геотермометров в различных геологических обстановках. Учитывая крупные масштабы сидеритового метасоматоза на Бакальских месторождениях, было принято предположение, что в микрообъёме породы устанавливается фактическое минеральное равновесие между анкеритом и сидеритом. Размер зерен метасоматических карбонатных минералов составляет десятки и сотни микрон, что вполне приемлемо для микрозондового анализа.

\section{Результаты}

Измерения выполнены для 7 проб, представляющих анкерит-сидеритовые контакты рудных залежей в различных участках Бакальского рудного поля (табл. 1). Пробы NB15, NB20 и Y1 расположены в западной части рудного поля на крупном Новобакальском месторождении (см. рис. 1). Они отобраны из различных частей бакальской свиты в рудоносных карбонатных пачках (низов - $\mathrm{b}_{2}{ }^{1}$, середины $\mathrm{b}_{2}{ }^{3}$ и верхов $-\mathrm{b}_{2}{ }^{7}$ ). Проба Вu10 представляет контакт рудной залежи в ВосточноБуландихинском карьере из центральной части рудного поля и расположена в самой верхней рудоносной карбонатной пачке $\mathrm{b}_{2}{ }^{9}$. Несколько восточнее данного карьера находится крупное месторождение Иркускан, где в Центральном карьере отобраны пробы в пределах средней части бакальской свиты IR2 $-\mathrm{b}_{2}{ }^{5}$, IR12 $-\mathrm{b}_{2}{ }^{3 \mathrm{~b}}$ и IR70 - $b_{2}{ }^{3 a}$.

Из всех точек измерения в табл. 1 указаны только составы анкеритов и сидеритов, имеющих минимальные и максимальные концентрации $\mathrm{FeCO}_{3}$, а также средние составы указанных минералов в каждой пробе. Видно, что состав контактовых анкеритов несколько различается: пробы из западной части рудного поля содержат меньше железа (при анализе средних значений $\mathrm{FeCO}_{3}$ варьирует от 11,77 до 18,54 мас. \%) и марганца и соответственно больше магния, чем пробы из центральной части (по средним значениям $\mathrm{FeCO}_{3}$ варьирует от 19,61 до 22,89 мас. $\%)$. 
Таблица 1. Состав сидеритов и анкеритов по данным микрозондирования, мас.\%

\begin{tabular}{|c|c|c|c|c|c|c|c|c|}
\hline Проба & Объект & Пачка & Состав* & $\mathrm{FeCO}_{3}$ & $\mathrm{MnCO}_{3}$ & $\mathrm{MgCO}_{3}$ & $\mathrm{CaCO}_{3}$ & Сумма \\
\hline \multirow[t]{6}{*}{ NB15 } & \multirow{6}{*}{$\begin{array}{l}\text { Новобакаль- } \\
\text { ский карьер, } \\
\text { южный борт, } \\
\text { гор. } 560 \text { м }\end{array}$} & \multirow[t]{6}{*}{$\mathrm{RF}_{1} \mathrm{~b}_{2}{ }^{1}$} & $\mathrm{Sd} / 12$ & 72,35 & 2,07 & 26,03 & 0,36 & 100,80 \\
\hline & & & Sd min & 69,42 & 1,73 & 29,25 & 0,4 & 100,80 \\
\hline & & & Sd max & 77,97 & 1,65 & 21,6 & 0,2 & 101,42 \\
\hline & & & Ank/16 & 15,51 & 0,63 & 31,80 & 51,85 & 99,78 \\
\hline & & & Ank min & 13,89 & 0,53 & 33,06 & 52,27 & 99,75 \\
\hline & & & Ank max & 17,38 & 0,75 & 30,09 & 51,35 & 99,57 \\
\hline \multirow[t]{6}{*}{ NB20 } & \multirow{6}{*}{$\begin{array}{l}\text { Новобакаль- } \\
\text { ский карьер, } \\
\text { юго- } \\
\text { восточный } \\
\text { борт, гор. } 560 \\
\text { м }\end{array}$} & \multirow[t]{6}{*}{$\mathrm{RF}_{1} \mathrm{~b}_{2}{ }^{3}$} & $\mathrm{Sd} / 11$ & 78,50 & 2,34 & 17,30 & 0,39 & 98,13 \\
\hline & & & Sd min & 74,45 & 2,32 & 23,04 & 0,23 & 99,81 \\
\hline & & & Sd max & 80,39 & 3,51 & 13,16 & 1,19 & 97,06 \\
\hline & & & Ank/11 & 18,54 & 0,87 & 28,91 & 51,18 & 99,49 \\
\hline & & & Ank min & 15,71 & 0,69 & 30,82 & 51,56 & 98,78 \\
\hline & & & Ank max & 21,12 & 0,95 & 27,65 & 51,18 & 100,90 \\
\hline \multirow[t]{6}{*}{ IR70 } & \multirow{6}{*}{$\begin{array}{l}\text { Центральный } \\
\text { Иркускан ка- } \\
\text { рьер, южный } \\
\text { борт, гор. } 635 \\
\text { м }\end{array}$} & \multirow[t]{6}{*}{$\mathrm{RF}_{1} \mathrm{~b}_{2}{ }^{3 \mathrm{a}}$} & $\mathrm{Sd} / 15$ & 74,52 & 3,53 & 20,05 & 0,35 & 98,10 \\
\hline & & & $\mathrm{Sd} \min$ & 72,53 & 2,81 & 22,43 & 0,33 & 97,77 \\
\hline & & & Sd max & 77,6 & 3,97 & 16,7 & 0,29 & 98,27 \\
\hline & & & Ank/5 & 22,89 & 1,49 & 24,21 & 51,06 & 99,64 \\
\hline & & & Ank min & 20,15 & 1,22 & 26,96 & 51,39 & 99,72 \\
\hline & & & Ank max & 24,23 & 1,63 & 22,92 & 50,75 & 99,53 \\
\hline \multirow[t]{6}{*}{ IR12 } & \multirow{6}{*}{$\begin{array}{l}\text { Центральный } \\
\text { Иркускан ка- } \\
\text { рьер, южный } \\
\text { борт, гор. } 635 \\
\text { м }\end{array}$} & \multirow[t]{6}{*}{$\mathrm{RF}_{1} \mathrm{~b}_{2}{ }^{3 \mathrm{~b}}$} & $\mathrm{Sd} / 10$ & 71,16 & 1,76 & 25,04 & 0,50 & 97,96 \\
\hline & & & $\mathrm{Sd} \min$ & 68,35 & 1,77 & 27,68 & 0,57 & 97,80 \\
\hline & & & Sd max & 74,59 & 1,77 & 22,19 & 0,4 & 98,55 \\
\hline & & & Ank/11 & 20,06 & 0,81 & 27,27 & 50,60 & 98,74 \\
\hline & & & Ank min & 10,15 & 0,36 & 35,99 & 52,47 & 98,97 \\
\hline & & & Ank max & 23,64 & 0,92 & 24,6 & 49,82 & 98,98 \\
\hline \multirow[t]{6}{*}{ IR2 } & \multirow{6}{*}{$\begin{array}{l}\text { Центральный } \\
\text { Иркускан ка- } \\
\text { рьер, запад- } \\
\text { ный борт, гор. } \\
645 \text { м }\end{array}$} & \multirow[t]{6}{*}{$\mathrm{RF}_{1} \mathrm{~b}_{2}{ }^{5}$} & $\mathrm{Sd} / 8$ & 71,45 & 2,34 & 24,60 & 0,36 & 98,75 \\
\hline & & & Sd min & 67,84 & 2,98 & 28,37 & 0,36 & 99,55 \\
\hline & & & Sd max & 74,18 & 2,41 & 21,51 & 0,3 & 98,40 \\
\hline & & & Ank/14 & 19,61 & 1,18 & 27,09 & 50,80 & 98,67 \\
\hline & & & Ank min & 18,57 & 1,09 & 28,22 & 51,09 & 98,97 \\
\hline & & & Ank max & 20,86 & 1,31 & 25,82 & 50,78 & 98,77 \\
\hline \multirow[t]{6}{*}{$\mathrm{Y} 1$} & \multirow{6}{*}{$\begin{array}{l}\text { Новобакаль- } \\
\text { ский карьер, } \\
\text { северо- } \\
\text { восточный } \\
\text { борт, гор. } 724 \\
\text { м }\end{array}$} & \multirow[t]{6}{*}{$\mathrm{RF}_{1} \mathrm{~b}_{2}{ }^{7}$} & $\mathrm{Sd} / 16$ & 71,90 & 1,71 & 24,58 & 0,46 & 98,19 \\
\hline & & & Sd min & 69,32 & 1,65 & 26,99 & 0,5 & 97,96 \\
\hline & & & Sd max & 75,18 & 1,61 & 22,1 & 0,2 & 98,89 \\
\hline & & & Ank/28 & 11,77 & 0,75 & 33,97 & 51,06 & 97,55 \\
\hline & & & Ank min & 9,69 & 0,51 & 35,86 & 51,32 & 97,38 \\
\hline & & & Ank max & 16,5 & 0,87 & \begin{tabular}{|l|}
28,78 \\
\end{tabular} & 49,41 & 95,56 \\
\hline \multirow[t]{6}{*}{ Bu10 } & \multirow{6}{*}{$\begin{array}{l}\text { Восточно- } \\
\text { Буландихин- } \\
\text { ский карьер, } \\
\text { северный } \\
\text { борт }\end{array}$} & \multirow[t]{6}{*}{$\mathrm{RF}_{1} \mathrm{~b}_{2}{ }^{9}$} & $\mathrm{Sd} / 9$ & 73,63 & 2,56 & 21,80 & 0,38 & 97,99 \\
\hline & & & $\mathrm{Sd} \min$ & 69,36 & 2,74 & 26,09 & 0,57 & 98,19 \\
\hline & & & Sd max & 78,78 & 1,81 & 17,64 & 0,27 & 98,23 \\
\hline & & & Ank/18 & 21,70 & 1,39 & 24,90 & 50,10 & 98,09 \\
\hline & & & Ank min & 20,16 & 1,17 & 25,79 & 50,37 & 97,49 \\
\hline & & & Ank max & 23,18 & 1,32 & 23,58 & 49,42 & 97,50 \\
\hline & Ank we & $/ 55$ & & 14,21 & 0,74 & 32,33 & 51,31 & 98,59 \\
\hline & Ank cen & $r / 48$ & & 20,84 & 1,21 & 26,01 & 50,52 & 98,57 \\
\hline & Sd wes & & & 73,90 & 2,00 & 22,97 & 0,41 & 98,98 \\
\hline & Sd cent & & & 72,94 & 2,67 & 22,48 & 0,39 & 98,17 \\
\hline
\end{tabular}

* - Sd - сидерит; Ank - анкерит; Sd/12 - средние значения для количества точек анализа, указанных в знаменателе; $\min$ и $\max$ - пробы с минимальными и максимальными значениями содержания $\mathrm{FeCO}_{3}$. 
Таблица 2. Температурные ограничения метасоматоза Бакальских сидеритовых месторождений по данным анкерит-сидеритового и анкерит-брейнеритового геотермометров

\begin{tabular}{|c|c|c|c|c|c|c|c|c|c|c|c|c|c|}
\hline \multirow[t]{2}{*}{ № } & \multirow{2}{*}{$\begin{array}{l}\text { Пары } \\
\text { сидерит- } \\
\text { анкерит* }\end{array}$} & \multicolumn{3}{|c|}{ NB15 } & \multicolumn{3}{|c|}{ NB20 } & \multicolumn{3}{|l|}{ Y1 } & \multicolumn{3}{|c|}{ IR70 } \\
\hline & & 1 & 2 & 3 & 1 & 2 & 3 & 1 & 2 & 3 & 1 & 2 & 3 \\
\hline 1 & $\begin{array}{l}\mathrm{Sd}_{\max } \\
\mathrm{Ank}_{\text {min }}\end{array}$ & 187 & 89 & 98 & 167 & 78 & 89 & 166 & 52 & 114 & 212 & 177 & 35 \\
\hline 2 & $\begin{array}{l}\mathrm{Sd}_{\max } \\
\mathrm{Ank}_{\max }\end{array}$ & 212 & 144 & 68 & 191 & 153 & 38 & 181 & 70 & 111 & 251 & 254 & -3 \\
\hline 3 & $\begin{array}{l}\mathrm{Sd}_{\mathrm{cp}} \\
\mathrm{Ank}_{\mathrm{cp}}\end{array}$ & 220 & 130 & 90 & 201 & 141 & 60 & 190 & 78 & 112 & 254 & 213 & 41 \\
\hline 4 & $\begin{array}{l}\mathrm{Sd}_{\text {min }} \\
\mathrm{Ank}_{\text {min }}\end{array}$ & 221 & 125 & 96 & 210 & 128 & 82 & 218 & 141 & 77 & 267 & 255 & 12 \\
\hline 5 & $\begin{array}{l}\mathrm{Sd}_{\min } \\
\mathrm{Ank}_{\max }\end{array}$ & 260 & 187 & 73 & 256 & 213 & 43 & 250 & 167 & 83 & 310 & 298 & 12 \\
\hline
\end{tabular}

Окончание табл. 2

\begin{tabular}{|c|c|c|c|c|c|c|c|c|c|c|}
\hline \multirow[t]{2}{*}{ № } & \multirow{2}{*}{$\begin{array}{l}\text { Пары } \\
\text { сидерит- } \\
\text { анкерит }\end{array}$} & \multicolumn{3}{|l|}{ IR2 } & \multicolumn{3}{|c|}{ IR12 } & \multicolumn{3}{|c|}{ Bu10 } \\
\hline & & 1 & 2 & 3 & 1 & 2 & 3 & 1 & 2 & 3 \\
\hline 1 & $\begin{array}{c}\mathrm{Sd}_{\text {max }} \\
\mathrm{Ank}_{\text {min }}\end{array}$ & 231 & 168 & 168 & 168 & 54 & 114 & 222 & 187 & 35 \\
\hline 2 & $\begin{array}{l}\mathrm{Sd}_{\max } \\
\mathrm{Ank}_{\max }\end{array}$ & 257 & 185 & 185 & 185 & 76 & 109 & 249 & 244 & 5 \\
\hline 3 & $\begin{array}{l}\mathrm{Sd}_{\mathrm{cp}} \\
\mathrm{Ank}_{\mathrm{cp}}\end{array}$ & 265 & 269 & 269 & 269 & 215 & 54 & 270 & 248 & 22 \\
\hline 4 & $\begin{array}{l}\mathrm{Sd}_{\min } \\
\mathrm{Ank}_{\text {min }}\end{array}$ & 278 & 284 & 284 & 284 & 269 & 15 & 290 & 243 & 47 \\
\hline 5 & $\begin{array}{l}\mathrm{Sd}_{\text {min }} \\
\mathrm{Ank}_{\text {max }}\end{array}$ & 315 & 344 & 344 & 344 & 315 & 29 & 333 & 310 & 23 \\
\hline
\end{tabular}

* - типы парагенезисов сидерита (Sd) и анкерита (Ank), выбраны средние (cp), минимальные $(\min )$ и максимальные (max) значения (см. табл. 1$) ; 1-\mathrm{T}^{\circ} \mathrm{C}$, термометр по Anovitz \& Essene, 1987; 2 - $\mathrm{T}^{\circ} \mathrm{C}$, термометр по Мартынову, 1990; 3 - разность между значениями термометров.

Если усреднить составы анкеритов периферийной (западной) и центральной частей рудного поля, то видно, что средние концентрации $\mathrm{FeCO}_{3}$ в анкеритах в первом случае (Ank west/55) заметно ниже $(14,21$ мас. \%), чем во втором (Ank centr/48), 20,84 мас. \% (см. табл. 1). При этом пропорционально изменяется и соотношение содержаний $\mathrm{MgCO}_{3}$, которое выше в анкеритах периферии (32,33 мас. \%) по сравнению с центральной частью рудного поля $(26,01$ мас. \%). В сидерите средние концентрации железа изменяются незакономерно в нешироких пределах (по средним значениям $\mathrm{FeCO}_{3}$ варьирует от 71,16 до 78,50 мас. \%), наблюдается оче- видный изоморфизм железа и марганца (по средним значениям $\mathrm{MnCO}_{3}$ варьирует от 1,71 до 3,53 мас. \%). В сидеритах примесь минала $\mathrm{MgCO}_{3}$ является постоянной и варьирует по средним значениям изученных проб от 17,3 до 26,03 мас. \%, что позволяет относить карбонаты железа Бакальских месторождений к сидероплезитам (Тимесков, 1963).

Данные по расчётам анкеритсидеритового и анкерит-брейнеритового термометров представлены в табл. 2. Температуры в каждой пробе рассчитаны для средних значений состава анкерита и сидерита, а также комбинации из точек анализа, имеющих минимальные и макси- 
мальные значения $\mathrm{FeCO}_{3}$ минералов метасоматического парагенеза. Это позволяет оценить возможные варианты изменения температуры во всём диапазоне концентраций $\mathrm{FeCO}_{3}$ в данном образце, т. е. получить представление о возможном диапазоне изменения температур в данной точке рудного поля. В табл. 2 значения размещены в порядке возрастания температуры, которая зависит от соотношения железистости в анкерите и сидерите. Ясно, что при одноактном и крупномасштабном метасоматическом воздействии в принципе должно было установиться минералогическое равновесие между составами одновременно кристаллизующихся анкерита и сидерита, соответствующее температуре данного процесса. Однако на деле картина значительно сложнее, и для каждого образца, в зависимости от его расположения в рудном поле, наблюдается определённое облако составов разных кристаллов метасоматических анкерита и сидерита.

Для всех изученных проб прослеживается одна тенденция в изменении расчетных температур. Минимальные температуры получены для варианта пары анкерит с минимальным значением $\mathrm{FeCO}_{3}$ и сидерит с максимальным (см. табл. 2). Самая высокая температура определяется для пары анкерит с максимальным значением $\mathrm{FeCO}_{3}$ и сидерит с минимальным. Для остальных соотношений анкерита и сидерита, как и для пары со средними арифметическими между всеми точками анализа анкерита и сидерита каждой пробы, получены промежуточные значения температур с постепенным возрастанием: пара анкерит с максимальным значением $\mathrm{FeCO}_{3}$ и сидерит с максимальным; пара анкерит и сидерит со средними значениями $\mathrm{FeCO}_{3}$; пара анкерит с минимальным значением $\mathrm{FeCO}_{3}$ и сидерит с минимальным.

\section{Обсуждение результатов}

Как было установлено ранее, метасоматическое образование сидерита в Ба- кальском рудном поле является следствием последовательного образования в доломитовой матрице сначала анкеритсодержащей области, возникновения в ней первых сидеритовых вростков, резкого разрушения анкеритовых зерен на контакте с образованием сидерита, наконец, полной равновесной сидеритизации (Демчук и др., 2003). Предельное насыщение анкерита железом, при котором начинается образование сидерита, для Бакальского рудного поля было в этом исследовании оценено как $10,7 \pm 0,8$ мас. \%. $\quad \mathrm{FeO} \%$ $\left(17,4 \pm 1,3\right.$ мас. \%. $\left.\mathrm{FeCO}_{3} \%\right)$.

В настоящем исследовании подтверждены и значительно детализированы данные по составу парагенезов анкерита и образующегося сидерита. Применение соотношений концентрации железа к термометрии показало, что самые высокие температуры получены для ассоциации наиболее железистого анкерита и наименее насыщенного железом сидерита (брейнерита). Эта закономерность вполне соответствует аналитическим экспериментальным данным (Мартынов, 1988; 1990; Rosenberg, 1967). Результаты сравнения расчетов по двум геотермометрам довольно показательны: при одинаковой тенденции изменения температур разность значений по ним составляет около $100^{\circ} \mathrm{C}$ при температурах по Мартынову (1990) ниже $250^{\circ} \mathrm{C}$. Но как только по этому термометру достигается $250^{\circ} \mathrm{C}$, разность вычисленных показаний между двумя термометрами резко снижается до значений менее $30^{\circ} \mathrm{C}$ (заявленная точность анкерит-брейнеритового геотермометра составляет $\pm 30^{\circ} \mathrm{C}$ ). Таким образом, при температурах выше $250^{\circ} \mathrm{C}$ оба термометра работают синхронно и в одном диапазоне в пределах заявленной точности (рис. 3), при более низких температурах термометр Мартынова сильно занижает показания относительно термометра Annovitz, Essene. В то же время следует уточнить, что Annovitz, Essene для расчёта термометра также использовали данные анализов природных карбонатов для 250, $400,500,700^{\circ} \mathrm{C}$. Отмечено, что точность 
термометра ухудшается «при низкой железистости фаз, то есть там, где изотермы распределения располагаются наиболее плотно» (Мартынов, 1990, с. 1695 см. рис. 6 этой статьи). Тем не менее при оценке температур гидротермального процесса ниже $250^{\circ} \mathrm{C}$ предпочтительно использовать термометр Annovitz, Essene, как учитывающий полный состав породообразующих элементов карбонатных парагенезов (не только $\mathrm{FeCO}_{3}$ и $\mathrm{MgCO}_{3}$, но также $\mathrm{CaCO}_{3}$ и $\mathrm{MnCO}_{3}$ ).
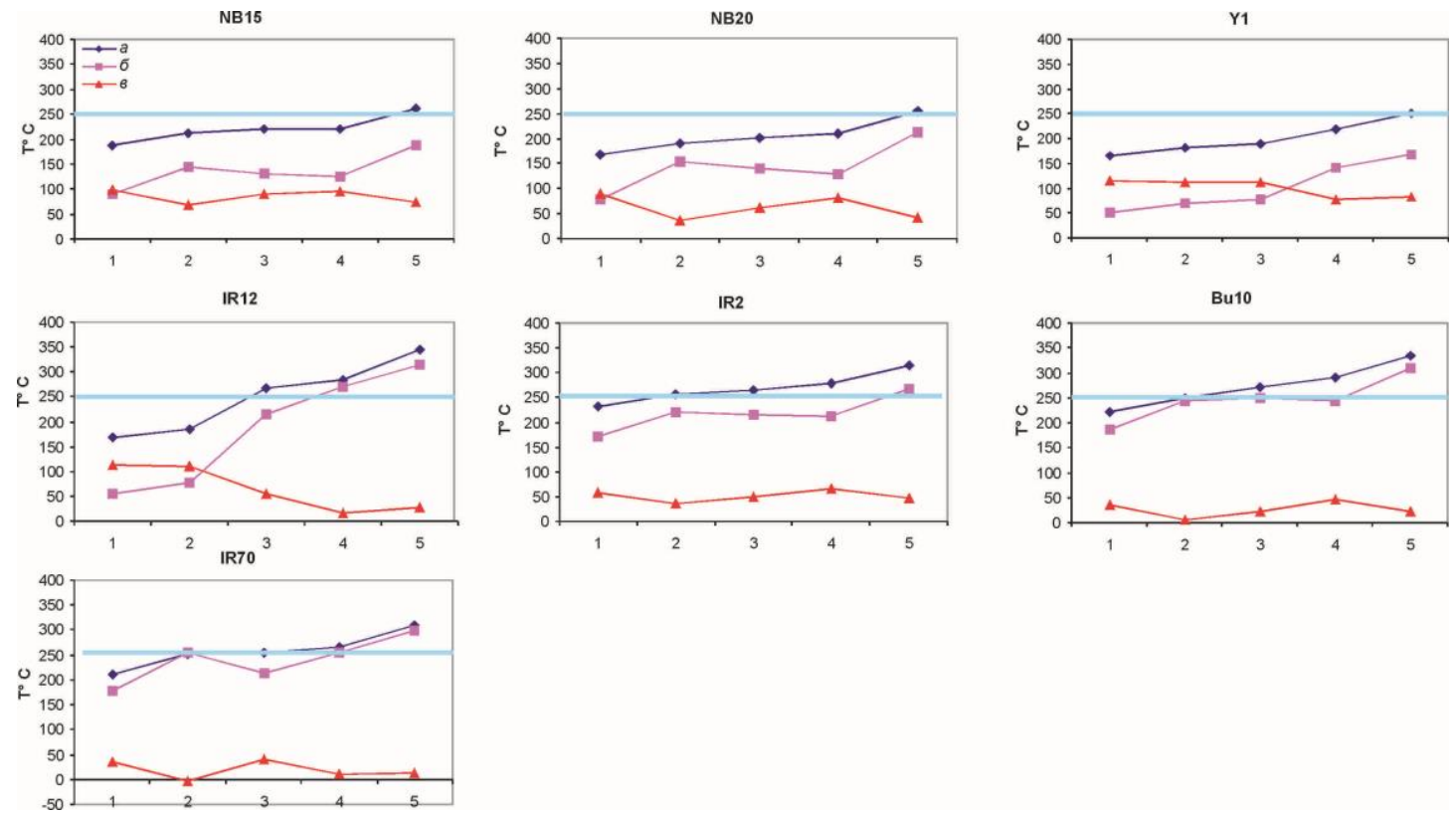

Рис. 3. Расчётные показания геотермометров для семи проб, отобранных в различных частях Бакальского рудного поля (номера проб над графиками): a -анкерит-сидеритового (Anovitz \& Essene, 1987); 6 - анкерит-брейнеритового (Мартынов, 1990); в - разность показаний геотермометров для расчётных парагенезов (точки 1-5 по оси абсиисс соответствуют левому столбиу табл. 1)

Расположение изученных проб в масштабе Бакальского рудного поля позволяет сделать выводы относительно распределения рудных растворов при их поступлении из глубинных зон земной коры. Наиболее низкие температуры метасоматоза установлены для проб из западной части рудного поля в Новобакальском месторождении (пробы NB15, NB20, Y1). Здесь температуры по средним составам анкерита и сидерита варьируют в интервале $190-220^{\circ} \mathrm{C}$, а максимальные едва достигают $250-260^{\circ} \mathrm{C}$ по данным геотермометра Annovitz, Essene соответственно; по данным геотермометра Мартынова они ещё ниже. В то же время в центральной части рудного поля, на месторождении Восточно-Буландихинское (проба Вu10) температуры по средним составам анкерита и сидерита достигают $270^{\circ} \mathrm{C}$, а мак- симальные $333^{\circ} \mathrm{C}$ по данным геотермометра Annovitz, Essene, при этом по термометру Мартынова они почти не отличаются, составляя соответственно $248^{\circ} \mathrm{C}$ и $310^{\circ} \mathrm{C}$. Несколько восточнее, но также в центральной части Бакальского рудного поля на месторождении Северо-Западный склон горы Иркускан (пробы IR2, IR12, IR70) получены высокие температуры для средних составов анкерита и сидерита $\left(254-269^{\circ} \mathrm{C}\right)$ и достаточно высокие максимальные значения температур $\left(310-344^{\circ} \mathrm{C}\right)$. Соответственно по данным геотермометра Мартынова температуры лишь незначительно отличаются (средние - $213-215^{\circ} \mathrm{C}$, максимальные - 268$\left.315^{\circ} \mathrm{C}\right)$.

Таким образом, установлена приуроченность наиболее высокотемпературных рудных растворов к центральной части 
Бакальского рудного поля (в среднем до $\left.250-270^{\circ} \mathrm{C}\right)$, в то же время в периферических частях средние температуры метасоматоза не превышали $190-220^{\circ} \mathrm{C}$.

Приуроченность наиболее высоких температур метасоматического замещения известняковой матрицы анкеритом и сидеритом к центральной части Бакальского рудного поля, установленная с помощью анкерит-сидеритового термометра в контактовых зонах сидеритовых рудных залежей, подтверждается и независимыми минералогическими критериями. В частности, было проведено изучение величины степени кристалличности гидрослюд и хлоритов из тонкой фракции (менее 2 мкм) глинистых сланцев и карбонатных пород бакальской свиты в пределах рудного поля и на его периферии. Значения данного параметра для бакальских сидеритов и даже некоторых вмещающих известняков находятся в области эпизоны, т. е. ниже величины 0.25 для рефлекса 001 иллита $2 \Theta^{\circ}$ (метод по Kisch, 1991), условно соответствующей области температур образования в интервале $250-300^{\circ} \mathrm{C}$ (Ellmies et al., 1999). Следует отметить, что в глинистых породах зигазинокомаровской свиты среднего рифея, перекрывающих рудоносную бакальскую свиту, в центральной части Бакальского рудного поля рентгеновским методом было обнаружено присутствие метаморфических минералов: стильпномелана и пирофиллита (Анфимов, 1997). Для других районов Башкирского мегантиклинория присутствие данных метаморфических минералов не характерно, за исключением зон метаморфических изменений в периферии Белорецкого метаморфического комплекса (термального купола, где метаморфизм в центральной части доходит до гранулитовой фации). Вероятно, в центральной части Бакальского рудного поля мы также имеем дело с повышенным термальным полем, своеобразным «термальным куполом», образование которого обусловлено мощной восходящей миграцией железоносных горячих флюидов по зонам разломов на этапе тектоно- термальной активизации и образования сидерита в многоэтажных залежах в 5 карбонатных пачках бакальской свиты. Время данного процесса, приведшего к масштабному сидеритовому метасоматозу, было оценено как $1010 \pm 100$ млн лет (Кузнецов и др., 2005).

Предполагается, что это был крупный этап деструкции в данной части восточной окраины континента Балтика, приведший к разуплотнению коры и активному подъёму флюидов из глубокопогруженных зон рифейского породного бассейна. По времени этот этап совпадает с накоплением карбонатно-терригенных отложений авзянской свиты и последующим крупным перерывом в осадконакоплении (Маслов и др., 2001). Он сопровождался не только крупной тектонической перестройкой региона, но и образованием ряда крупных стратиформных месторождений, прежде всего барит-полиметаллических в отложениях авзянской свиты, а также ряда месторождений и проявлений магнезита и, вероятно, залежей метасоматического анкерита в карбонатных горизонтах этой свиты (Крупенин, 2004), а также крупного Исмакаевского магнезитового и Суранского флюоритового месторождений в карбонатных породах суранской свиты нижнего рифея (Крупенин и др., 2016).

Время прохождения метасоматоза, приуроченное к границе среднего и верхнего рифея $(1010 \pm 100$ млн лет (Кузнецов и др., 2005)), позволяет предполагать, что вмещающая толща бакальской свиты была погружена на глубину не более 4-5 км под отложениями среднего рифея (Маслов и др.,2001). Следовательно, породы в условиях нормального геотермического градиента имели температуру не более $120-150^{\circ} \mathrm{C}$. Рудные флюиды, внедрившиеся из глубоких горизонтов земной коры, имели более высокую температуру. Причиной относительно низкотемпературного сидеритообразования в периферии Бакальского рудного поля следует считать процесс остывания рудных флюидов при миграции по рудораспределяющим каналам, поскольку часть их 
энергии тратилась на дополнительный нагрев вмещающей терригенно-карбонатной толщи бакальской свиты.

\section{Краткие выводы}

1.Состав околорудных анкеритов в западной и центральной частях Бакальского рудного поля несколько отличается: средние концентрации $\mathrm{FeCO}_{3}$ в анкеритах составляют соответственно 14,21 и 20,84 мас. \%, в то время как в составе сидероплезита разных частей рудного поля нет выраженных различий.

2.Наблюдается близкое совпадение данных расчета по анкерит-сидеритовому и анкерит-брейнеритовому термометрам и оценке степени кристалличности глинистых пород при температурах $250^{\circ} \mathrm{C}$ и выше. При температурах ниже $250^{\circ} \mathrm{C}$ предпочительнее использовать анкеритсидеритовый термометр (Annovitz, Essene, 1987), показывающий более плавное изменение температур в этом диапазоне.

3. Температура сидеритового метасоматоза не зависит от положения сидеритовой залежи в стратиграфическом разрезе бакальской свиты, но зависит от положения в структуре Бакальского рудного поля: составляет в центральной части в среднем $250-270^{\circ} \mathrm{C}$, в то время как в периферической части средние температуры метасоматоза не превышают $190-220^{\circ} \mathrm{C}$.

4. Материалы по составу карбонатных парагенезов, изложенные в настоящей публикации, могут дать дополнительную информацию для совершенствования природных карбонатных геотермометров для низко-среднетемпературных гидротермально-метасоматических процессов.

Автор выражает благодарность Т. Наgenbruk, PhD R. Ellmies из Технического универститета, Берлин (ФРГ), за помощь в выполнении микрозондовых анализов, А.И.Малышеву (ИГГ УрО РАН) за консультации в использовании программного языка BASIC.

\section{Библиографический список}

Анфимов Л.В. Литогенез в рифейских осадочных толщах Башкирского мегантиклинория
(Ю.Урал) / УрО РАН. Екатеринбург, 1997. $288 \mathrm{c}$.

Анфимов Л.В., Бусыгин Б.Д., Крупенин М.Т. Закономерности распределения железа в породах рифейской сидеритовой формации Бакал (Южный Урал) // Литология и полезные ископаемые. 1984. № 4. С. 136-143.

Демчук И.Г., Крупенин М.Т., Сазонов В.Н. Механизм полистадийного образования сидерита в Бакальском рудном поле (Южный Урал) // Зап. ВМО. 2003. № 5. С. 86-93.

Заварицкий А.Н. К вопросу о происхождении железных руд Бакала. М.: Изд-во АН СССР, 1939. $40 \mathrm{c}$.

Крупенин М.T. Условия формирования сидеритоносной бакальской свиты нижнего рифея (Южный Урал) / УрО РАН. Екатеринбург, 1999. $256 \mathrm{c}$.

Крупенин М.T. Минерагеническое и геодинамическое значение среднерифейского времени на западном склоне Южного Урала // Доклады РАН. 2004. Т.399, № 4. С.503-505.

Крупенин М.Т., Кузнецов А.Б., Константинова Г.В. Сравнительная $\mathrm{Sr}-\mathrm{Nd}$ систематика и распределение РЗЭ в типовых магнезитовых месторождениях нижнего рифея ЮжноУральской провинции // Литосфера. 2016. № 5. C. $58-80$.

Кузнечов А.Б., Крупенин М.Т., Овчинникова Г.В., Горохов И.М., Маслов А.В. Каурова O.К., Эльмис Р. Формирование и преобразование карбонатных пород и сидеритовых руд бакальской свиты нижнего рифея (Южный Урал): Sr-изотопная характеристика и $\mathrm{Pb}-\mathrm{Pb}$ возраст // Литология и полезные ископаемые. 2005. № 3. С. 227-249.

Мартынов К.B. Топологический анализ и экспериментальное изучение минеральных равновесий в системе $\mathrm{CaO}-\mathrm{MgO}-\mathrm{FeO}-\mathrm{H}_{2} \mathrm{O}-\mathrm{CO}_{2}-\mathrm{O}_{2}$ при $250-450^{\circ} \mathrm{C}$ и $P 1000$ бар // Геохимия. 1988. № 9. C. 1319-1329.

Мартынов К.В. Экспериментальное изучение распределения $\mathrm{Mg}$ и $\mathrm{Fe}$ между твёрдыми растворами анкерита и брейнерита в системе $\mathrm{MgCO}_{3}-\mathrm{CaCO}_{3}-\mathrm{FeCO}_{3}$ при $250-450^{\circ} \mathrm{C}$ и термодинамические свойства анкерита // Геохимия. 1990. № 12. С. 1688-1695.

Маслов А.В., Крупенин М.Т., Гареев Э.З., Ан-

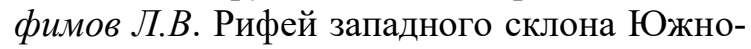
го Урала (классические разрезы, седиментои литогенез, минерагения, геологические памятники природы) / УрО РАН. Екатеринбург, 2001. T. I. 352 c. 
Тимесков В.А. Минералогия карбонатных руд и вмещающих их карбонатных пород Бакальского железорудного месторождения на Южном Урале. Казань: Изд-во Казанского ун-та, 1963. $213 \mathrm{c.}$

Яниикий А.Л., Сергеев О.П. Бакальские железорудные месторождения и их генезис. М.: Изд-во АН СССР, 1962. $112 \mathrm{c.}$

Annovitz L.M. \& Essene E.J. Phase equilibria in the system $\mathrm{CaCO}_{3}-\mathrm{MgCO}_{3}-\mathrm{FeCO}_{3} / /$ Journal of Petrology. 1987. Vol. 28. Part 2. P. 389-414.

Ellmies R., Voightlaunder G., Germann K., Krupenin M.T., Moeller P., Origin of giant stratabound deposits of magnesite and siderite in Riphean carbonate rocks of the Bashkir mega-anticline, western Urals. Geologische Rundschau. 1999. Vol. 87. P. 589-602.

Kisch H.J. Illite crystallinity: recommendations on samples preparation, X-ray diffraction settings and interlaboratory samples // J. Metam Geol. 1991. Vol. 9. P. 665-670.

Prochaska W., Krupenin M.T., Evidence of Inclusion Fluid Chemistry for the Formation of Magnesite and Siderite Deposits in the Southern Urals // Mineralogy and Petrology. 2013. Vol. 107, №1. P. 53-65.

Rosenberg P.E. Subsolidus relations in system $\mathrm{CaCO}_{3}-\mathrm{MgCO}_{3}-\mathrm{FeCO}_{3}$ between 350 and $550^{\circ} \mathrm{C}$ // American Mineralogist. 1967. Vol.52, № 5-6. P.787-797.

\title{
Temperature Range for Metasomatism at the Bakalskoe Siderite Deposits with Use of Geochemical Data
}

\author{
M.T. Krupenin \\ Institute of Geology and Geochemistry, Ural Branch of the Russian Academy \\ of Sciences, 15 Academician Vonsovskii Str., Ekaterinburg 620016, Russia \\ E-mail: krupenin@igg.uran.ru
}

The data obtained with the quantitative microprobe ankerite-siderite composition analysis of seven samples from the different parts of Bakalskoe field showed that the wallrock ankerites in the western and central parts of the ore field differ in average concentrations of $\mathrm{FeCO}_{3}$ (respectively 14.21 and 20.84 wt.\%). However, there is no significant difference in composition of siderites. The calculation of the $\mathrm{Mg}-\mathrm{Fe}$ metasomatism temperatures based on ankerite-siderite and ankerite-breinerite geothermometers showed the close agreement of the values of both methods at temperatures of $250{ }^{\circ} \mathrm{C}$ and above. The average temperatures of siderite metasomatism in the central part of the Bakalskoe ore field are in range $250-270^{\circ} \mathrm{C}$, and, in the peripheral part, the determined temperature does not exceed $190-220^{\circ} \mathrm{C}$. These values do not depend on the position of the siderite deposits in stratigraphic level of the Bakalskaya Suite.

Key words: metasomatism; dolomite; ankerite; breinerite; siderite; geothermometer;

Riphean.

\section{References}

Anfimov L.V. 1997. Litogenez v rifeyskikh osadochnykh tolshchakh Bashkirskogo megantiklinoria (Yu. Ural) [Lithogenesis in Riphean sedimentary strata of Bashkirskiy megaanticlinorium (South Urals)]. Yekaterinburg, Ural Branch of Russian Academy of Science, p. 288. (In Russian).

Anfimov L.V., Busygin B.D., Krupenin M.T. 1984. Zakonomernosti raspredeleniya zheleza $\mathrm{v}$ porodakh rifeyskoy sideritovoy for- matsii Bakal (Yuzhnyy Ural) [Regularities of iron distribution in the rocks of the Riphean Bakal siderite formation (South Urals)]. Lithologiya i poleznye iskopaemye. 4:136-143. (In Russian).

Demchuk I.G., Krupenin M.T., Sazonov V.N. 2003. Mekhanizm polistadiynogo obrazovaniya siderita $\mathrm{v}$ Bakalskom rudnom pole (Yuzhnyy Ural) [The mechanism of multistage siderite formation in the Bakalskoe ore field (Southern Urals)]. Zap. WMO. 5:86-93. (In Russian). 
Zavaritskiy A.N. 1939. K voprosu o proiskhozhdenii zheleznykh rud Bakala [On the origin of the Bakal iron ore]. Moskva, Publishing House of the USSR Academy of Sciences, p. 40. (In Russian).

Krupenin M.T. 1999. Usloviya formirovaniya sideritonosnoy bakalskoy cvity nizhnego rifeya (Yuzhnyy Ural) [Conditions of formation of siderite-bearing Lower Riphean Bakal Suit (South Urals)]. Ekaterinburg, Ural Branch of Russian Academy of Science, p. 256. (In Russian).

Krupenin M.T. 2004. Mineragenicheskoe i geodinamicheskoe znachenie srednerifeyskogo vremeni na zapadnom sklone Yuzhnogo Urala [The Middle Riphean Time on the western slope of the South Urals: Mineragenic and Geodynamic Implications]. Doklady RAN. Earth Science. 399(4):1189-1191.

Krupenin M.T., Kuznetsov A.B., Konstantinova G.V. 2016. Sravnitelnaya Sr-Nd sistematika i raspredelenie RZE $\mathrm{v}$ tipovykh magnezitovykh mestorozhdeniyakh YuzhnoUralskoy provintsii [Comparative Sr-Nd systematics and REE distribution in the typical magnesite deposits in Lower Riphean stratigraphic sequence of South Urals province]. Lithosfera. 5:58-80. (In Russian).

Kuznetsov A. B., Krupenin M. T., Ovchinnikova G. V., Gorokhov I. M., Maslov A. V., Kaurova O. K., Ellmies R.. 2005. Formirovanie i preobrazovanie karbonatnykh porod i sideritovykh rud bakalskoy svity nizhnego rifeya [Diagenesis of Carbonate and Siderite Deposits of the Lower Riphean Bakal Formation, the Southern Urals: Sr Isotopic Characteristics and $\mathrm{Pb}-\mathrm{Pb}$ Age]. Lithology and Mineral Resources. 40(3):195-215.

Martynov K.V. 1988. Topologicheskiy analiz i eksperimentalnoe izuchenie mineralnykh ravnovesiy v sisteme $\mathrm{CaO}-\mathrm{MgO}-\mathrm{FeO}-\mathrm{H}_{2} \mathrm{O}$ $-\mathrm{CO}_{2}-\mathrm{O}_{2}$ pri $250-450^{\circ} \mathrm{C}$ i $P 1000$ bar [Topological analysis and experimental study of mineral equilibria in the system $\mathrm{CaO}-\mathrm{MgO}$ $\mathrm{FeO}-\mathrm{H} 2 \mathrm{O}-\mathrm{CO}_{2}-\mathrm{O}_{2}$ at $250-450{ }^{\circ} \mathrm{C}$ and 1000 bar P]. Geochemistry International. 9:13191329.

Martynov K.V. 1990. Experimentalnoe izuchenie raspredeleniya $\mathrm{Mg}$ i $\mathrm{Fe}$ mezhdu tverdymi rastvorami ankerita $\mathrm{i}$ breinerita $\mathrm{v}$ sisteme $\mathrm{MgCO}_{3}-\mathrm{CaCO}_{3}-\mathrm{FeCO}_{3}$ pri $250-450^{\circ} \mathrm{C}$ i termodinamicheskie svoystva ankerita [Experi- mental study of $\mathrm{Mg}$ and $\mathrm{Fe}$ distribution between solid solutions ankerite and breinerite in $\mathrm{MgCO}_{3}-\mathrm{CaCO}_{3}-\mathrm{FeCO}_{3}$ system at $250-450^{\circ}$ $\mathrm{C}$, and the thermodynamic properties of ankerite] Geochemistry International. 12:16881695.

Maslov A.V., Krupenin M. T, Gareev A.Z., Anfimov L.V. 2001. Riphey zapadnogo sklona Yuzhnogo Urala (classicheskie razrezy, sedimento-litogenez, minerageniya, geologicheskie pamyatniki prirody). [Riphean of the Western slope of the South Urals (classic sections, sedimento-lithogenesis, minerageny, geological monuments of nature]. Vol.1. Yekaterinburg, UB RAS, p. 351. (In Russian).

Timeskov V.A. 1963. Mineralogiya karbonatnykh rud i vmechshayushshikh ikh karbonatnykh porod Bakalskogo zhelezorudnogo mestorozhdenia na Yuzhnom Urale [Mineralogy of carbonate ore and hosting carbonate rocks of the Bakalskoe iron ore deposit in the South Urals). Kazan, Publishing House of Kazan University Press, p. 213. (In Russian).

Janicki A.L., Sergeev O.P. 1962. Bakalskie zhelezorudnye mestorozhdenia i ikh genesis. [Bakalskie iron ore deposits and their genesis]. Moskva, Publishing House of the USSR Academy of Sciences, p. 112. (In Russian).

Annovitz L.M. \& Essene E.J., 1987. Phase equilibria in the system $\mathrm{CaCO}_{3}-\mathrm{MgCO}_{3}-\mathrm{FeCO}_{3}$. Journal of Petrology. 28(2):389-414.

Ellmies R., Voightlaunder G., Germann K., Krupenin M.T., Moeller P., 1999. Origin of giant stratabound deposits of magnesite and siderite in Riphean carbonate rocks of the Bashkir mega-anticline, western Urals. Geologische Rundschau. 87:589-602.

Kisch H.J. 1991. Illite crystallinity: recommendations on samples preparation, X-ray diffraction settings and interlaboratory samples. J. Metam. Geol. 9:665-670.

Prochaska W., Krupenin M.T., 2013. Evidence of Inclusion Fluid Chemistry for the Formation of Magnesite and Siderite Deposits in the Southern Urals. Mineralogy and Petrology. 107(1):53-65.

Rosenberg P.E. 1967. Subsolidus relations in system $\mathrm{CaCO}_{3}-\mathrm{MgCO}_{3}-\mathrm{FeCO}_{3}$ between 350 and $550^{\circ} \mathrm{C}$. American Mineralogist. 52(56):787-797. 